\title{
Black Pioneers, Intermetropolitan Movers, and Housing Desegregation
}

by

\author{
Richard Sander \\ University of California, Los Angeles
}

\section{Yana Kucheva}

CUNY

\begin{abstract}
CES 16-23
March, 2016

The research program of the Center for Economic Studies (CES) produces a wide range of economic analyses to improve the statistical programs of the U.S. Census Bureau. Many of these analyses take the form of CES research papers. The papers have not undergone the review accorded Census Bureau publications and no endorsement should be inferred. Any opinions and conclusions expressed herein are those of the author(s) and do not necessarily represent the views of the U.S. Census Bureau. All results have been reviewed to ensure that no confidential information is disclosed. Republication in whole or part must be cleared with the authors.

To obtain information about the series, see www.census.gov/ces or contact Fariha Kamal, Editor, Discussion Papers, U.S. Census Bureau, Center for Economic Studies 2K132B, 4600 Silver Hill Road, Washington, DC 20233, CES.Papers.List@census.gov. To subscribe to the series, please click here.
\end{abstract}




\begin{abstract}
In this project, we examine the mobility choices of black households between 1960 and 2000 . We use household-level Decennial Census data geocoded down to the census tract level. Our results indicate that, for black households, one's status as an intermetropolitan migrant especially from an urban area outside the South - is a powerful predictor of pioneering into a white neighborhood. Moreover, and perhaps even more importantly, the ratio of these intermetropolitan black arrivals to the incumbent metropolitan black population is a powerful predictor of whether a metropolitan area experiences substantial declines in housing segregation.
\end{abstract}

Any opinions and conclusions expressed herein are those of the authors and do not necessarily represent the views of the U.S. Census Bureau. All results have been reviewed to ensure that no confidential information is disclosed. 
The Great Migration - the fifty-year era during which some six million AfricanAmericans moved from the rural South to the urban North - is such an epochal event in black history that it can crowd out our consideration of other important black migrations. The migration of rural, southern blacks to southern cities in the fifty years after the Civil War; the return migration of many northern blacks to the (usually urban) South during the Great Migration; and the massive immigration since the mid-1960s of blacks from West Africa and the West Indies - all of these have received less than their due in scholarship on black urban patterns.

In this article, we examine yet another black migration: the movement of AfricanAmericans from one metropolitan area to another over the past fifty years, and especially the acceleration of this migration in the 1970s. Our initial interest in these migrants grew out of the idea that inter-metropolitan black movers might provide a valuable insight into the effect of fair housing laws; if such laws significantly reduced the cost of moving into white neighborhoods, then the effects should be particularly visible in the locational choices of black households arriving in urban areas from other parts of the country. As we examined the phenomenon, we not only found strong confirmation of this hypothesis, but also evidence that intermetropolitan black moves into predominantly white neighborhoods played a powerful role in whether urban areas experienced significant desegregation in the 1970s and 1980s.

\section{Framework and Hypotheses}

When households move within metropolitan areas, their choices are heavily influenced by their current location. Established commuting patterns, stable job locations, school enrollment, the nearby presence of family and friends, connection to churches and other 
neighborhood institutions - all of these influences militate in favor of shorter compared to longer moves. An analysis by William Clark (1980) of intraurban moves in Omaha, Nebraska found that $43 \%$ of intraurban moves by whites in the late 1970 s were to locations within two miles of one's former home; taking into account the relative location of all whites in Omaha, this implies that a housing unit within two miles of one's home was roughly twenty times more likely to be a destination than a unit farther away.

Clark's analysis also found that $72 \%$ of black household moves were to locations within two miles of one's former home; this is unsurprising, both because black neighborhoods throughout America tend to be concentrated in denser portions of metropolitan areas, and because black housing choices have been historically constrained by housing discrimination.

Black mobility was nonetheless evolving in important ways during the mid-century decades. In the 1930s and 1940s, blacks in most urban areas were ghettoized in small residential districts with fairly rigid borders. Starting at the end of the 1940s, large-scale white-to-black neighborhood transitions became common; these transitions almost always occurred along existing black-white borders, with the "invasion-success" pattern documented by Duncan and Duncan (1955) and Taeuber and Taeuber (1965) and often facilitated by blockbusting real estate agents (Helper, 1969; Satter , 2009). ${ }^{1}$ This means that a new "band" of housing was perpetually opening for blacks during the 1950s and 1960s, relieving sometimes intense overcrowding in the old ghettos and producing specific destinations where blacks might find better housing, better neighborhood services, and (at least temporarily) integrated living conditions. By the 1960s, a

\footnotetext{
${ }^{1}$ We have argued elsewhere that the commencement of this "border expansion" pattern was triggered by the Supreme Court's 1948 decision in Shelley v. Kraemer, which greatly weakened the enforceability of restrictive covenants; another important factor was the growth of white suburbanization, which eased white demand for inner-city housing (Kucheva and Sander 2014).
} 
high proportion of African-American households in most major cities were living in housing units that had been recently occupied by whites.

A few cities passed limited fair housing laws, prohibiting discrimination in public housing, as early as the late 1940s; over the next twenty years fair housing laws, first among cities and then among states, gradually but unevenly spread to include private acts of discrimination. None of these ordinances and statutes had aggressive enforcement mechanisms; though there are many recorded instances where individual housing providers were pressured into relaxing discriminatory policies, there were almost no successful lawsuits against housing discriminators and the effect of these laws appears to have been marginal (Collins 2004, 2006).

In April 1968, the U. S. Congress passed the Fair Housing Act (FHA), which covered the vast majority of the housing market by the end of 1969, and created meaningful enforcement mechanisms both through private litigation and, especially, through the Justice Department. ${ }^{2}$ In June 1968, the Supreme Court held in Jones v. Mayer that the Civil Rights Act of 1866 also broadly prohibited private discrimination based on race, thus in effect further narrowing exemptions in the FHA. A wide variety of evidence, both from paired testing and from more qualitative sources, suggests that housing discrimination rates fell sharply in the 1970s, but scholars widely dispute the degree to which markets became genuinely open to AfricanAmerican homeseekers during this period (or in any later period) (Hirsch 1983; Sugrue 1996).

Of course, one can learn much about how black housing opportunities changed by examining intra-metropolitan migration patterns. Table 1, for example, shows the black presence

${ }^{2}$ Jonathan Zasloff, "The Secret History of the Fair Housing Act," 53 Harvard J. on Legislation 247 (2016), examines how scholars have tended to greatly understate the actual enforcement powers granted by the Fair Housing Act to the Justice Department, and DOJ's aggressive use of those power in the early 1970 s. 
in the top half of census tracts in several major metropolitan areas, ranked by the proportion of whites in each tract. The table vividly conveys that even in those neighborhoods that were most overwhelmingly white, blacks made some inroads in the 1970s. Still, black moving patterns in the 1970s were radically different from those of whites, and it is difficult to infer how much of this difference was due to the traditional centripetal forces constraining all movers, and how much was due to external barriers in the housing market.

In assessing how fair housing laws affected the freedom of neighborhood choice for African-Americans, our theoretical ideal would be a set of "free-agent" households considering neighborhoods without reference to any existing neighborhood ties, and even without reference to any racial preferences. Such an ideal does not exist; but it is useful to consider how the locational choices of newly-arriving households in an urban area will differ from households already there.

In the case of a white, middle-class household moving from, say, Buffalo to Indianapolis, we can imagine a few influences: the location of a job, the location of any friends and acquaintances who live in the Indianapolis area, and word-of-mouth about attractive neighborhoods. These different influences will play a larger or smaller role in particular cases, but our a priori prediction is that the household is more likely to end up in a white, middle-class neighborhood than other neighborhoods; in other words, the moving household will end up in a neighborhood that is socioeconomically and spatially similar to the neighborhood it has left.

White immigrants from another country, especially those who do not speak English, are likely to be influenced by some special factors. They face significant barriers to interacting freely in the general neighborhood marketplace, and significant advantages if they can locate in or near a community that shares their language and culture. As many ethnographers have documented, 
new immigrants often cluster among fellow-countrymen in urban areas, producing what is called “port-of-entry" segregation (Cutler et al. 1998). In other words, white immigrants may make locational choices that are narrower and, in effect, more constrained than those of incumbent whites in the metro area.

During the Great Migration, blacks migrating from the South are generally thought to have followed this "port of entry" model. They were coming from an environment where interactions with whites that did not follow a ritualized script could be quite dangerous; they were unlikely to "pioneer" in a white neighborhood (Lehman 1990). Very commonly, Southern migrants were following friends or relatives, and at least initially lived with them. The migrants thus predominantly settled in established black neighborhoods.

We can imagine, however, that an African-American household moving from one northern urban area to another - say, from Buffalo to Indianapolis - in the 1960s, 1970s, or 1980s, might have a very different calculus. They would of course be aware of civil rights legislation, including open housing laws, and they would be aware that some black pioneers were moving into white neighborhoods. Surveys taken throughout this period (especially in the 196075 period) showed large majorities of blacks wanted to live in neighborhoods that were more integrated than their current neighborhood, and most blacks thought that public services were better in white than black neighborhoods (Pettigrew 1973). Our prospective émigrés from Buffalo might thus have two conflicting impulses. On the one hand, they would probably appreciate the benefits of seeking a "port-of-entry" neighborhood, where they could at least initially settle and determine the lay of the land. On the other, the appeal of pioneering, and the locational independence stemming from moving to a new urban area, might make them unusually close to the ideal "free agent" we described earlier. As economists might put it, 
intermetropolitan black movers might have unusually high "elasticity" in preferences across predominantly white and predominantly black neighborhoods, depending on their perceptions (and the reality) of how fairly they would be treated in white neighborhoods. They might thus provide a valuable barometer of how the evolution of national fair housing policy affected actual behavior on the ground.

Since there is virtually no existing literature on such movers, we did not know when we began this research what patterns we might find. But the above discussion motivates a clear line of research. First, we wanted to divide major American urban areas into three zones: (a) established black areas; (b) a transitional "zone" near these areas where black neighborhood expansion into nearby white areas might be occurring on a substantial scale; (c) the rest of the urban area. Then, we wanted to identify recent African-American movers, and divide them into three groups: (1) those moving within the urban area (intra-metropolitan movers); (2) new arrivals from the South; and (3) new arrivals from the North or West; these latter would overwhelmingly be "inter-metropolitan" movers, since virtually all blacks living in those regions were urban blacks.

With these categories, we could advance several hypotheses:

i) Starting in the 1950s, if fair housing law and changing racial attitudes lowered barriers to African-Americans in white neighborhoods, we should see a steady increase of black moves into zone (c) communities in major metropolitan areas.

ii) Such shifts should be more pronounced for blacks in category (3), above, than blacks in category (1). In other words, we would expect that over the 1960s and 1970s, and particularly after 1970, intermetropolitan black movers in the North and West will show an increased propensity to move into zone (c) communities. 
iii) Among black movers (in all categories - 1, 2, and 3) we expect that those with higher education and higher income will be more likely to move into zone (c) communities.

If hypothesis (ii) is confirmed by the data, this raises a further interesting question: are category (3) movers numerous enough to actually affect metropolitan patterns of segregation? It is well known that some urban areas experienced large drops in housing segregation during the 1970s, as measured by either the index of dissimilarity or the exposure index, while many others experienced only small drops or even increases during the decade. If intermetropolitan black movers are in fact much more likely to respond to improved open housing environments, and if their aggregate moves are numerous in some urban areas and vary significantly across urban areas, it is plausible that this group might have important effects on metropolitan areas as a whole. This could happen in two distinct ways: first, the simple fact of more moves to zone (c) could lower segregation, and second, the presence of more blacks in zone (c) could itself affect the residential choices of subsequent black movers in all three categories.

\section{Data and Methods}

Analyses of the kind we describe above are almost impossible to do with public-release census data. Data available for small geographic areas, such as block groups or census tracts, generally are not available by race and migration status when the number of respondents of a particular race is small; thus one's capacity to study blacks who "pioneer" into white areas is intrinsically limited. Detailed microdata are available for 1970 and 1980 only at the very large aggregations (e.g., cities, suburban rings, counties); for 1990 and later years a good deal of data are available for Public Use Microdata Areas (PUMAs), but these areas have populations of 100200,000 and are thus too coarse to distinguish neighborhoods with nearly sufficient resolution. 
Other national longitudinal samples, such as the PSID and NLSY, provide rich information on migration (and would be valuable to analyze as a complement to this study) but do not have a sufficient volume of households to capture, for example, patterns of black migration to urban areas with relatively modest black populations.

The Federal Statistical Research Data Center (RDC) program sponsored by the Census and a community of research universities thus offers unique advantages. Through the RDC mechanism, the Census provides secure access to microdata with detailed geographic identifiers; thus, all the questions asked in the Census long form can be tied, at the person and household level, to the census tract level or (for some decades) even the block level. These files currently start with the 1960 Census and continue to fairly recent American Community Survey microdata. Because such detailed and geographically detailed data may be vulnerable to re-identification, however, the RDC process significantly limits what analyses can be disclosed, and imposes other constraints on the research process.

We made use of the long-form Decennial Census files for 1960, 1970, 1980, 1990, and 2000. Before the onset of the ACS, the decennial Census attempted to survey every household in the nation with either a short form (sent to every household) or a long form. The "short-form" questionnaire was limited to an enumeration of the number of persons in each household, and the race, age, and relationship to the household "head" of each person. The "long-form" questionnaire, sent to a sample of roughly one-sixth of all households, asked dozens of additional questions about the education, occupation, earnings, citizenship, fertility, and other characteristics of each household member, as well as many questions about the housing unit occupied by the entire household. We use data from the long-form because we need data on household income in addition to demographic data on household size, presence of children, and 
the age of the householder. We excluded from our analysis persons in group quarters and any population outside of metropolitan areas.

In 2010, the decennial census dispensed with the long form, focusing instead on a complete "short-form" count of the total population. Replacing the long form was the ACS, which substantively covers nearly the same topics that were formerly on the long form. The great advantage of the ACS is that, since it is conducted annually, we have available at any given time (with a two-year lag) fairly current data on American households, and it is possible to understand changes that occur between census years in a way we formerly could not. Using the ACS presents two disadvantages for our analyses. First, the ACS asked heads of households for their metropolitan area of residence one year ago (as opposed to five years ago). This makes comparisons between the ACS and the Decennial Census mobility questions impossible. Second, each year's ACS sample is far smaller (about 1\% of all households) than the old long-form Census data (15-20\% of all households). We thus confine our analysis to the 1960 through 2000 censuses. $^{3}$

We conduct all of our analyses at the household level and create variables that describe the socioeconomic composition of each household along with the metropolitan area of each household. Our key dependent variable categorizes African American heads of household into a) recent movers whose current census tract is at least 2 miles away from a majority black census tract (outlying move); b) recent movers whose current census tract is less than 2 miles away from a majority black census tracts (periphery move); and c) recent movers whose census tract is

\footnotetext{
${ }^{3}$ We have conducted all analyses in this paper for the 2006-2010 ACS data as well. These results are available from the authors upon request. All regression results with the 2006-2010 ACS data show similar patterns to the ones produced with the 1960-2000 Decennial Census data despite differences in the scope of the migration questions.
} 
majority black (core move). Recent movers are those who moved into their current residence over the last 15 months. We model the probability of making each either an outlying, periphery, or core move using a series of multinomial logistic regressions for each decennial census year between 1960 and 2000 .

We construct two key independent variables: a) whether the household head is a newcomer to their current metropolitan area; and b) whether the household head lived in the South immediately before moving to their current metropolitan area. Both of these variables measure the mobility status of household heads 5 years prior to each Census. In 1980, the Census only coded at random the answers to the five-year migration questions for about $55 \%$ of all respondents. We, therefore, adjust our 1980 estimates to reflect the random coding procedure.

We also created the following set of control variables describing the household head: age, household composition, educational attainment, income, and tenure. Finally, our models control for metropolitan-level variables, such as total population, percent black, the metropolitan dissimilarity index, and whether the metropolitan area is in the South.

In order to avoid endogeneity in our regression models, we classify households as movers only if they had moved in the year prior to each Census. In this way, all household-level socioeconomic variables are measured as contemporaneously as possible with the decision to move to a different neighborhood. Moreover, we compute all neighborhood- and metropolitanlevel independent variables only for the population that did not move in the year prior to each census. Therefore, these metropolitan-level measures precede temporally the mobility behavior of black pioneers.

Throughout our discussion, we focus on developments within American metropolitan areas, including many comparisons across decades. To maintain comparable units of analysis, we 
used 1980 definitions of Standard Metropolitan Statistical Areas to describe the metropolitan population across all decades. This approach allows us to study constant geographic units over time, but as a result we exclude newer suburban enclaves. Thus, our analysis excludes moves to new suburban neighborhoods and might understate the extent to which African Americans made pioneering moves more than 2 miles from established black areas.

\section{Results}

We begin with a national picture, considering metropolitan America as a whole. Over the period from the late 1950 s to the late 1990 s, the rate at which blacks arrive in new metropolitan areas from elsewhere very gradually increases. In 1960, the proportion of metropolitan blacks who lived outside that metro area in 1955 is $10.5 \%$; by 2000, the comparable proportion is about $11.5 \%$. During that time, however, the shape of migration changes substantially.

In the 1960 census, our data shows that just over 19\% of all black households in metropolitan areas had moved into their current address since the beginning of 1959 (roughly a 15-month window). Using the three zones we described earlier, we find that $63 \%$ of these moves were into units within the "core" black zone (areas that were at least 50\% black in 1959), 31\% of moves were into units along the "periphery" of the core, and $6 \%$ of moves were into "outlying" tracts - that is, tracts that were at least two miles from the nearest black "core" tract.

This picture is very consistent with what we know about urban black segregation during the late 1950s. African-Americans were highly segregated (the weighted mean black/white index of dissimilarity in these metro areas was .87 in 1960), but blockbusting was occurring along the border (what we call the periphery) of existing black communities. By the late 1950s, restrictive 
covenants were of little use to whites trying to prevent black entry. ${ }^{4}$ Many of the movers into the periphery were middle-class blacks buying homes in areas that had once been impenetrable because of racial covenants, but were now transitioning from white to black occupancy in a geographically incremental way. Thus, although the "periphery" as we define it contained only a small fraction of the white-occupied housing units, it was the very disproportionate choice of blacks moving out of the existing ghetto.

The tracts we describe as "outlying" would have often, but not always, been predominantly white areas that were unlikely to be reached in the near future by block-by-bock expansion of the black core. However, they would also include many areas where a small segregated black community lived in a largely white area, such as small enclaves of housing built near new factories for black workers during World War II, or rural housing in the South that was in the path of metropolitan expansion, and was thus gradually being bought up by developers to convert into suburban housing. Consequently, when we find that $6 \%$ of $1959-60$ urban black moves were to these outlying areas, it would be incorrect to conclude that all, or even a majority, of these moves were of black households achieving genuine long-term integration with white neighbors; the number should, however, roughly correlate with the true number of such moves, and comparisons across time should tell us about the increase in black moves to white areas.

How did this pattern of moves look for recent arrivals to metropolitan areas? Table 2 shows the distribution of black moves for "incumbents" and "new arrivals" in American metro areas between 1960 and 2010. In the 1959-60 period, the most significant difference for our

\footnotetext{
${ }^{4}$ Shelley v. Kraemer (1948) forbade courts from granting injunctions against black homebuyers moving into homes covered by restrictive covenants; Barrows v. Jackson (1953) rendered covenants unenforceable against white homeowners selling to blacks. The available evidence suggests that covenants thereafter rapidly lost any effectiveness in forestalling black neighborhood expansion.
} 
analysis, and one consistent with our first hypothesis, is that "new arrivals" were about 2.3 times more likely than "incumbents" to move into outlying areas. This gap is large enough, when one also takes into account the greater representation of "new arrivals" among all movers, to mean that the new-arrival households accounted for $43 \%$ of all black moves to outlying areas.

Our second hypothesis is that the "new arrivals," as a class, should be a particularly good barometer of improved fair housing conditions. The 1960s, of course, witnessed the dramatic passage of major civil rights laws, and opinion and social surveys show a steady increase in white acceptance of ideas of housing integration and equal rights, but major fair housing legislation occurred only at the very end of the decade. A number of northern and western states, and many cities in those two regions, had adopted some sort of fair housing statute or ordinance by the mid-1960s, but these laws generally had very weak enforcement provisions, and studies have found that they had little on-the-ground effect. Congress passed, and President Johnson signed, the federal Fair Housing Act in April 1968, but some key provisions of the law did not go into effect until the end of 1969, and active enforcement of the law (primarily by the U.S. Justice Department) took a few years to mobilize. The changes we see in move locations in 1969-70, compared with 1959-60, are significant but not profound (see Table 2). The proportion of black moves coming to "outlying" areas grew by nearly half during the 1960 s, but the pattern is not dramatically different in 1969-70 than a decade before. It is worth noting, however, that some metropolitan areas that registered a decline in overall black-white segregation during the 1960s also had particularly large numbers of new black arrivals.

The 1980 census provides a much more striking contrast. It is during the 1970s that the Justice Department brought lawsuits against dozens of major owners of rental complexes, real estate operators, and real estate agents, with federal courts consistently interpreting the reach of 
the Fair Housing Act broadly. It is also during the 1970s that systematic fair housing testing methods began to document sharp - even dramatic - declines in rates of housing discrimination in white markets. Whether discrimination actually declined has been the subject of much debate, largely because levels of black/white segregation barely budged in many metropolitan areas. But Table 2 shows that the 1970s brought a sharp change in the pattern of black moves.

The proportion of black movers going to outlying areas increases by about $130 \%$ between 1969-70 and 1979-80 - an increase that is far more striking for the "new arrivals" because one is starting from a much higher $1969-70$ base, even though the proportional increase is about the same for incumbents and new arrivals. It is with the 1979-80 data that we can see the logic of our second hypothesis born out. African-American households who are arriving or have recently arrived in metropolitan areas are less likely to be subject to the sorts of influences that bias local moves towards relatively short distances (ties to neighbors, schools, churches, family and jobs); they are likely to be more influenced than incumbents by changes in local housing market conditions - in this case, by an exogenous decline in the prevalence of housing discrimination.

By 1979-80, the distribution of moves by black "new arrivals" is not dramatically out of sync with the actual distribution of housing units in metropolitan areas. In other words, our focus on the moves of "new arrivals" in metro areas strongly indicates that, during the 1970s, black residential mobility fundamentally changed, and access to white markets sharply increased.

The data for 1989-90 and 1999-2000 reveals a further interesting twist. The 1989-90 period shows a further progression from the 1979-80 patterns; both black incumbents and black new arrivals show yet further increases in the propensity to move into units in outlying areas. The distribution of black "new arrival" moves, compared with the overall distribution of housing units, converges still further. But in 1999-2000, the trend appears to reverse; for both incumbents 
and new arrivals, the propensity to move to outlying areas declines. This is partly due to the steady decline in the proportion of census tracts that qualify as "outlying", because of the steady increase in the number and dispersion of census tracts that are at least $50 \%$ black. Still, there is a decrease in the 1990s, even taking this trend into account.

In supplementary analyses, we examined the percent of new arrivals and incumbents who moved across metropolitan areas only in the North and the West (see Table 3). As we note above, we expect African American movers between Northern and Western metropolitan areas to be more likely to pioneer to outlying neighborhoods compared to movers from the South. Indeed, the contrast between incumbents and new arrivals, in terms of moving to outlying neighborhoods, is greater in 1959-60 and 1969-70 when we exclude Southern movers, but this difference erodes after 1970. We come back to this point in the discussion of our regression results below.

Why "new arrivals" were more adventurous pioneers

We do not as yet have interview data that lets us compare the locational decisions of new arrivals in SMSAs with incumbents, but we do know, from census data, many of their demographic characteristics. In Table 4, we present a mutinomial logistic regression predicting whether a household moving in the fifteen months before the census chose an outlying neighborhood, whether a household chose a periphery neighborhood or whether a household chose a core neighborhood. The table includes a regression for each of the five census periods 
between 1960 and 2000. The reference category in the table are households who moved to core neighborhoods. ${ }^{5}$

As Tables 2 and 3 imply, being a new arrival substantially increases the likelihood that one will move into an outlying tract. The propensity of newcomers to move to outlying areas is also evident in our multinomial analyses. In order to facilitate, comparisons across years we have generated predicted probabilities of moving into outlying areas for newcomers to a metropolitan area (see Table 5). We present predicted probabilities for a model with no controls and a model that includes our full set of household-level and metropolitan-level controls presented in Table 3. The most prominent finding in our multinomial regression models is that the probability of making a move to an outlying area almost triples between 1970 and 1980 and remains high thereafter. Moreover, the household-level and metropolitan-level controls in our regressions do not take away the statistical significance of the coefficient on newcomers nor diminish substantially the absolute strength of the relationship. This result provides strong support for our second hypothesis that newcomers to metropolitan areas especially after the 1970s would be much more likely to pioneer to outlying areas.

Next, we turn to other interesting patterns in our multinomial models in Table 4. In the 1959-60 and 1969-70 analyses, residence in the South 5 years ago is a negative predictor of moving to an outlying area. This is in line with our initial hypotheses: migrants from the rural South tended to seek the safety and networks of the core, in the mold of traditional immigrants settling in port-of-entry neighborhoods. The Southern effect, however, disappears entirely in

\footnotetext{
${ }^{5}$ We have also implemented logistic regression models where we do not disaggregate moves to peripheral and core areas. In addition, we have implemented logistic regression models that do not drop non-movers from the sample. These models show substantially the same results and are available upon request from the authors.
} 
1979-1980 and 1989-90, and then, in 1999-2000 becomes a positive predictor of moving to an outlying area. We believe this shift reflects both the post-1970 increase in integration in southern urban areas, and the increased tendency of Southern migration after 1980 to represent movement from metropolitan areas, rather than migration from the rural South.

Our multinomial results also support our third hypothesis. Moving to an outlying area is significantly associated with having higher levels of education, being married with children, and being a home owner rather than a renter. On the other hand, living in a more segregated and larger metropolitan area, with a larger percentage of African American residents, dampens the odds of making a move to an outlying area.

\section{Newcomer Pioneers and Desegregation}

Our analysis and discussion up to this point has focused on one main point: AfricanAmerican newcomers to metropolitan areas from the North and West were substantially more likely than incumbent households to pioneer in areas outside the black core, and starting in the 1970s they pioneered in large numbers in outlying areas that were unlikely to re-segregate. This illustrates both the desire of African-American households to seek out conditions of long-term integration with whites (when they were not constrained by other locational choice factors), and their greatly increased ability to do so starting in the 1970s. The question we now consider is whether these newcomers played an important role in whether an urban area actually did desegregate.

We note, first, that the absolute number of newcomer pioneers in outlying areas was large. In 1979-80, nearly half of all the black moves occurring in outlying areas were made by newcomers. Second, the volume of black migration, relative to the incumbent black population, 
varied widely in the 1970s and 1980s. The Great Migration had largely run its course by the end of the 1960s. Many of the urban areas that had been magnets for blacks during the Great Migration were in the throes of deindustrialization by the early 1970s. Thus, in Chicago, the proportion of blacks who had moved there between 1975 and 1980 (relative to the total 1980 black population) was only 4\%; in Detroit and Cleveland, only $5 \%$ of the black population had moved in between 1970 and 1980 (see Table 6). In contrast, many western metropolitan areas experienced black in-migration on a relatively large scale during the 1970s. In San Diego, the proportion of blacks who had moved there between 1975 and 1980 was 36\%. In San Jose and Phoenix, the proportions were $36 \%$ and $23 \%$, respectively. Some Southern metropolitan areas also experienced substantial population growth in the 1970s, as the "Sunbelt boom" gathered steam, and these areas, too, had substantial black in-migration. In Austin, 21\% of African American residents had moved into the metropolitan area over the 1975-1980 period. In Houston and Miami $12 \%$ and $16 \%$ of black residents were newcomers.

The correlation between the relative size of the black "newcomer" population in a metropolitan area in 1975-1980 and that area's change in black/white dissimilarity between 1970 and 1980 is .64 for the top 60 metropolitan areas with the largest black population. In other words, the relative size of the newcomer African American population explains $42 \%$ of the drop in black/white segregation between 1970 and 1980 (see Table 7). We are currently exploring further this linkage using Census RDC data.

\section{Conclusion}

In this paper, we develop and combine two insights into how black/white integration comes about. First is the idea of focusing on intermetropolitan black migrants, who, we 
hypothesize, may reveal to us more about black housing choices across different types of neighborhoods, and about changing mobility options, than do blacks moving within a metropolitan area. Second is the idea of distinguishing between two types of black moves into white neighborhoods, separating black moves into areas that abut, or are very close to, existing black neighborhoods, from black moves into areas that are a substantial distance from existing black concentrations. The second type of move, we suggest, is much less likely to be part of a blockbusting episode or otherwise part of a rapid, en masse process of racial transition; these black moves far from black areas are more likely to happen when general rates of housing discrimination decline, and they are themselves more likely to beget meaningful, long-term housing integration.

Using Census RDC data, which makes it possible to separate out local from intermetropolitan black movers at detailed geographies like census tracts, we show that these intermetropolitan blacks were indeed much more likely than local blacks to move into outlying white areas, and that the volume of such moves dramatically increased after 1970. This coincides with other recent research about when fair housing laws became effective, and when housing discrimination rates began to sharply decline.

The increase in black mobility to outlying white areas occurred nationally in the 1970s, but the volume of intermetropolitan black movers - relative to the incumbent black population varied dramatically across different metropolitan areas. Urban areas in the Northeast and Midwest, which were experiencing large losses of manufacturing jobs in the 1970s, had relatively few new black arrivals from other metro areas; some of the more dynamic southern metro areas had many more arrivals, and western urban areas had the most. These patterns of 
intermetropolitan migration correlate highly with patterns of black/white desegregation during the 1970s. We believe there is a causal linkage, and will explore this linkage in further work. 


\section{References}

Clark, William A. 1980. "Residential mobility and neighborhood change: some implications for racial residential segregation." Urban Geography 1(2): 95-117.

Collins, William J. 2004. "The Housing Market Impact of State Level Anti-Discrimination Laws, 1960-1970." Journal of Urban Economics 55(3): 534-564.

Collins, William J. 2006. “The Political Economy of State Fair Housing Laws Before 1968.” Social Science History 30(1): 15-49.

Cutler, David M., Edward L. Glaeser, and Jacob L. Vigdor. 2008. "When are ghettos bad? Lessons from immigrant segregation in the United States." Journal of Urban Economics 63(3): 759-774.

Duncan, Otis D. and Beverly Duncan. 1955. "A methodological analysis of segregation indexes." American Sociological Review. 20(2): 210-217.

Helper, Rose. 1969. Racial Policies and Practices of Real Estate Brokers. University of Minnesota Press.

Hirsch, Arnold R. 1983. Making the second ghetto: Race and Housing in Chicago, 1940-1960. Cambridge University Press.

Kucheva, Yana and Richard Sander. 2014. "The Misunderstood consequences of Shelley v. Kraemer." Social Science Research 48: 212-233.

Lehman, Nicholas. 1991. The Promised Land: The Great Black Migration and How It Changed America. New York: Alfred A. Knopf.

Pettigrew, Thomas F. 1973. "Attitudes on race and housing: a social-psychological view." In Segregation in Residential Areas, eds. Amos H. Hawley and Vincent P. Rock. Washington, D.C.: National Academy of Sciences.

Satter, Beryl, 2009. Family Properties. Metropolitan Books.

Sugrue, Thomas. 1996. The Origins of the Urban Crisis: Race and Inequality in Postwar Detroit. Princeton, NJ: Princeton University Press.

Taeuber, Karl E. and Alma F. Taeuber. 1969. Negroes in Cities: Residential Segregation and Neighborhood Change. Atheneum.

Zasloff, Jonathan. 2016. "The Secret History of the Fair Housing Act." 53 Harvard J. on Legislation 247. 
Table 1. Number of blacks in the "whitest half" of metropolitan-area census tracts, 1970-1990

\begin{tabular}{lrrr}
\hline Metro area & 1970 & 1980 & 1990 \\
\hline Atlanta & 1,557 & 8,220 & 23,031 \\
Chicago & 231 & 2,073 & 12,086 \\
Dallas-Fort Worth & 185 & 6,665 & 30.851 \\
Detroit & 0 & 273 & 1,319 \\
Houston & 625 & 11,876 & 26.24 \\
Los Angeles & 1,392 & 17,943 & 40,974 \\
Minneapolis & 137 & 979 & 3,513 \\
Philadelphia & 3,543 & 7,881 & 15,200 \\
Richmond & 1,303 & 7,422 & 13,618 \\
\hline 50 Largest Metro Areas & 71,559 & 255,952 & 521,457 \\
\hline
\end{tabular}


Table 2. Distribution of African-American household destinations, all U.S. metropolitan areas

\begin{tabular}{rcccccc}
\hline & \multicolumn{6}{c}{ Type of Area } \\
\cline { 2 - 7 } Years & \multicolumn{2}{c}{ Core } & \multicolumn{2}{c}{ Periphery } & \multicolumn{2}{c}{ Outlying } \\
\cline { 2 - 7 } & $\begin{array}{c}\text { Moves by } \\
\text { SMSA } \\
\text { incumbents }\end{array}$ & $\begin{array}{c}\text { Moves by } \\
\text { SMSA new } \\
\text { arrivals }\end{array}$ & $\begin{array}{c}\text { Moves by } \\
\text { SMSA } \\
\text { incumbents }\end{array}$ & $\begin{array}{c}\text { Moves by } \\
\text { SMSA new } \\
\text { arrivals }\end{array}$ & $\begin{array}{c}\text { Moves by } \\
\text { SMSA } \\
\text { incumbents }\end{array}$ & $\begin{array}{c}\text { Moves by } \\
\text { SMSA new } \\
\text { arrivals }\end{array}$ \\
\cline { 2 - 7 } $1959-1960$ & $66 \%$ & $55 \%$ & $30 \%$ & $36 \%$ & $4 \%$ & $9 \%$ \\
$1969-1970$ & 65 & 52 & 31 & 35 & 6 & 14 \\
$1979-1980$ & 60 & 35 & 27 & 33 & 13 & 32 \\
$1989-1990$ & 56 & 32 & 27 & 32 & 17 & 38 \\
$1999-2000$ & 60 & 42 & 25 & 31 & 16 & 29 \\
\hline
\end{tabular}


Table 3. Distribution of African-American household destinations, North and West metropolitan areas

\begin{tabular}{ccccccc}
\hline & \multicolumn{9}{c}{ Type of Area } \\
\cline { 2 - 7 } Years & \multicolumn{2}{c}{ Core } & \multicolumn{2}{c}{ Periphery } & \multicolumn{2}{c}{ Outlying } \\
\cline { 2 - 7 } & $\begin{array}{c}\text { Moves by } \\
\text { SMSA } \\
\text { incumbents }\end{array}$ & $\begin{array}{c}\text { Moves by } \\
\text { SMA new } \\
\text { arrivals }\end{array}$ & $\begin{array}{c}\text { Moves by } \\
\text { SMSA } \\
\text { incumbents }\end{array}$ & $\begin{array}{c}\text { Moves by } \\
\text { SMSA new } \\
\text { arrivals }\end{array}$ & $\begin{array}{c}\text { Moves by } \\
\text { SMSA } \\
\text { incumbents }\end{array}$ & $\begin{array}{c}\text { Moves by } \\
\text { SMSA new } \\
\text { arrivals }\end{array}$ \\
\cline { 2 - 7 } $1959-1960$ & $61 \%$ & $47 \%$ & $36 \%$ & $42 \%$ & $3 \%$ & $11 \%$ \\
$1969-1970$ & 60 & 41 & 35 & 43 & 5 & 16 \\
$1979-1980$ & 62 & 36 & 26 & 31 & 12 & 33 \\
$1989-1990$ & 56 & 32 & 27 & 28 & 15 & 40 \\
$1999-2000$ & 60 & 42 & 25 & 25 & 16 & 33 \\
\hline
\end{tabular}


Table 4. Multinomial logistic regression of pioneering moves by black household heads

\begin{tabular}{|c|c|c|c|c|c|}
\hline & $\begin{array}{c}1960 \\
\text { odds ratios }\end{array}$ & $\begin{array}{c}1970 \\
\text { odds ratios }\end{array}$ & $\begin{array}{c}1980 \\
\text { odds ratios }\end{array}$ & $\begin{array}{c}1990 \\
\text { odds ratios }\end{array}$ & $\begin{array}{c}2000 \\
\text { odds ratios }\end{array}$ \\
\hline \multicolumn{6}{|c|}{ Pioneer move more than $2 \mathrm{mi}$ away from black enclave (outlying move) } \\
\hline Newcomer to SMSA & $\begin{array}{c}2.632 * * * \\
(0.067)\end{array}$ & $\begin{array}{c}2.156^{* * *} \\
(0.055)\end{array}$ & $\begin{array}{c}2.200 * * * \\
(0.044)\end{array}$ & $\begin{array}{c}2.464 * * * \\
(0.037)\end{array}$ & $\begin{array}{c}1.891 * * * \\
(0.025)\end{array}$ \\
\hline Not in sample for SMSA moves & & & $\begin{array}{c}1.271 * * * \\
(0.023)\end{array}$ & & \\
\hline Residence in the south 5 years ago & $\begin{array}{c}0.761 * * * \\
(0.027)\end{array}$ & $\begin{array}{c}0.724 * * * \\
(0.025)\end{array}$ & $\begin{array}{c}0.972 \\
(0.022)\end{array}$ & $\begin{array}{c}0.961 \\
(0.021)\end{array}$ & $\begin{array}{c}1.109 * * * \\
(0.022)\end{array}$ \\
\hline Age & $\begin{array}{c}1.003^{* * *} \\
(0.001)\end{array}$ & $\begin{array}{c}1.003 * * * \\
(0.001)\end{array}$ & $\begin{array}{c}0.989 * * * \\
(0.001)\end{array}$ & $\begin{array}{c}0.987 * * * \\
(0.001)\end{array}$ & $\begin{array}{c}0.994 * * * \\
(0.000)\end{array}$ \\
\hline \multicolumn{6}{|c|}{ Household structure (married with child omitted) } \\
\hline Single female with child & $\begin{array}{c}0.490 * * * \\
(0.020)\end{array}$ & $\begin{array}{c}0.530 * * * \\
(0.019)\end{array}$ & $\begin{array}{c}0.489 * * * \\
(0.011)\end{array}$ & $\begin{array}{c}0.580 * * * \\
(0.012)\end{array}$ & $\begin{array}{c}0.586^{* * *} \\
(0.011)\end{array}$ \\
\hline Single male with child & $\begin{array}{c}0.620 * * * \\
(0.069)\end{array}$ & $\begin{array}{c}0.657 * * * \\
(0.064)\end{array}$ & $\begin{array}{c}0.702 * * * \\
(0.030)\end{array}$ & $\begin{array}{c}0.697 * * * \\
(0.022)\end{array}$ & $\begin{array}{c}0.696^{* * *} \\
(0.019)\end{array}$ \\
\hline Married no child & $\begin{array}{c}0.769 * * * \\
(0.024)\end{array}$ & $\begin{array}{c}0.837 * * * \\
(0.028)\end{array}$ & $\begin{array}{c}1.141^{* * *} \\
(0.028)\end{array}$ & $\begin{array}{c}1.114 * * * \\
(0.029)\end{array}$ & $\begin{array}{l}1.059^{*} \\
(0.026)\end{array}$ \\
\hline Single female & $\begin{array}{c}0.421 * * * \\
(0.021)\end{array}$ & $\begin{array}{c}0.488^{* * *} \\
(0.022)\end{array}$ & $\begin{array}{c}0.754 * * * \\
(0.019)\end{array}$ & $\begin{array}{c}0.868 * * * \\
(0.022)\end{array}$ & $\begin{array}{c}0.795^{* * *} \\
(0.016)\end{array}$ \\
\hline Single male & $\begin{array}{c}0.662 * * * \\
(0.030)\end{array}$ & $\begin{array}{c}0.664 * * * \\
(0.027)\end{array}$ & $\begin{array}{c}0.810^{* * *} \\
(0.017)\end{array}$ & $\begin{array}{c}0.829 * * * \\
(0.019)\end{array}$ & $\begin{array}{c}0.804 * * * \\
(0.016)\end{array}$ \\
\hline \multicolumn{6}{|l|}{ Education ( $<$ HS diploma omitted) } \\
\hline Education: HS diploma & $\begin{array}{c}0.989 \\
(0.031)\end{array}$ & $\begin{array}{c}1.267 * * * \\
(0.037)\end{array}$ & $\begin{array}{c}1.636^{* * *} \\
(0.031)\end{array}$ & $\begin{array}{c}1.497 * * * \\
(0.029)\end{array}$ & $\begin{array}{c}1.501 * * * \\
(0.027)\end{array}$ \\
\hline Education: Some college & $\begin{array}{c}0.954 \\
(0.045)\end{array}$ & $\begin{array}{c}1.937 * * * \\
(0.069)\end{array}$ & $\begin{array}{c}2.403 * * * \\
(0.049)\end{array}$ & $\begin{array}{c}2.120 * * * \\
(0.042)\end{array}$ & $\begin{array}{c}2.051 * * * \\
(0.036)\end{array}$ \\
\hline Education: College + & $\begin{array}{l}1.145^{*} \\
(0.073)\end{array}$ & $\begin{array}{c}3.627 * * * \\
(0.167)\end{array}$ & $\begin{array}{c}4.159 * * * \\
(0.112)\end{array}$ & $\begin{array}{c}3.219 * * * \\
(0.085)\end{array}$ & $\begin{array}{c}3.421 * * * \\
(0.074)\end{array}$ \\
\hline Total income (In '000s) & $\begin{array}{c}0.946^{* * *} \\
(0.005)\end{array}$ & $\begin{array}{c}1.023 * * * \\
(0.002)\end{array}$ & $\begin{array}{c}1.029 * * * \\
(0.001)\end{array}$ & $\begin{array}{c}1.016^{* * *} \\
(0.001)\end{array}$ & $\begin{array}{c}1.005 * * * \\
(0.000)\end{array}$ \\
\hline Owner & $\begin{array}{c}2.518 * * * \\
(0.073)\end{array}$ & $\begin{array}{c}1.898 * * * \\
(0.055)\end{array}$ & $\begin{array}{c}1.026 \\
(0.022)\end{array}$ & $\begin{array}{c}1.078^{* * *} \\
(0.022)\end{array}$ & $\begin{array}{c}1.494 * * * \\
(0.023)\end{array}$ \\
\hline MSA population (in ' 000,000 s) & $\begin{array}{c}0.998 * * * \\
(0.000)\end{array}$ & $\begin{array}{c}0.993 * * * \\
(0.000)\end{array}$ & $\begin{array}{c}0.995 * * * \\
(0.000)\end{array}$ & $\begin{array}{c}0.996 * * * \\
(0.000)\end{array}$ & $\begin{array}{c}0.993 * * * \\
(0.000)\end{array}$ \\
\hline MSA percent black & $\begin{array}{c}0.911 * * * \\
(0.002)\end{array}$ & $\begin{array}{c}0.913 * * * \\
(0.002)\end{array}$ & $\begin{array}{c}0.912 * * * \\
(0.001)\end{array}$ & $\begin{array}{c}0.926^{* * *} \\
(0.001)\end{array}$ & $\begin{array}{c}0.932 * * * \\
(0.001)\end{array}$ \\
\hline MSA Dissimilarity index & $\begin{array}{c}0.000 * * * \\
(0.000)\end{array}$ & $\begin{array}{c}0.000 * * * \\
(0.000)\end{array}$ & $\begin{array}{c}0.001 * * * \\
(0.000)\end{array}$ & $\begin{array}{c}0.005 * * * \\
(0.000)\end{array}$ & $\begin{array}{c}0.009 * * * \\
(0.001)\end{array}$ \\
\hline
\end{tabular}




\begin{tabular}{|c|c|c|c|c|c|}
\hline Current MSA in South & $\begin{array}{c}1.742 * * * \\
(0.074)\end{array}$ & $\begin{array}{c}1.602 * * * \\
(0.066)\end{array}$ & $\begin{array}{c}1.872 * * * \\
(0.039)\end{array}$ & $\begin{array}{c}1.496 * * * \\
(0.039)\end{array}$ & $\begin{array}{c}0.830 * * * \\
(0.019)\end{array}$ \\
\hline Constant & $\begin{array}{c}177.773 * * * \\
(21.518)\end{array}$ & $\begin{array}{c}293.079 * * * \\
(35.889)\end{array}$ & $\begin{array}{c}117.735 * * * \\
(8.245)\end{array}$ & $\begin{array}{c}36.428 * * * \\
(2.271)\end{array}$ & $\begin{array}{c}21.958 * * * \\
(1.182) \\
\end{array}$ \\
\hline \multicolumn{6}{|c|}{ Pioneer move less than $2 \mathrm{mi}$ away from black enclave (periphery move) } \\
\hline Newcomer to SMSA & $\begin{array}{c}1.268 * * * \\
(0.018)\end{array}$ & $\begin{array}{c}1.289 * * * \\
(0.021)\end{array}$ & $\begin{array}{c}1.423 * * * \\
(0.025)\end{array}$ & $\begin{array}{c}1.551 * * * \\
(0.022)\end{array}$ & $\begin{array}{c}1.421 * * * \\
(0.017)\end{array}$ \\
\hline Not in sample for SMSA moves & & & $\begin{array}{l}1.040 * * \\
(0.015)\end{array}$ & & \\
\hline Residence in the south 5 years ago & $\begin{array}{c}0.840 * * * \\
(0.018)\end{array}$ & $\begin{array}{c}0.772 * * * \\
(0.018)\end{array}$ & $\begin{array}{c}0.911 * * * \\
(0.017)\end{array}$ & $\begin{array}{c}0.856^{* * *} \\
(0.018)\end{array}$ & $\begin{array}{l}0.959 * \\
(0.017)\end{array}$ \\
\hline Age & $\begin{array}{c}0.998 * * * \\
(0.000)\end{array}$ & $\begin{array}{c}0.996 * * * \\
(0.001)\end{array}$ & $\begin{array}{c}0.989 * * * \\
(0.000)\end{array}$ & $\begin{array}{c}0.988 * * * \\
(0.000)\end{array}$ & $\begin{array}{c}0.993 * * * \\
(0.000)\end{array}$ \\
\hline \multicolumn{6}{|c|}{ Household structure (married with child omitted) } \\
\hline Single female with child & $\begin{array}{c}0.930 * * * \\
(0.016)\end{array}$ & $\begin{array}{c}0.857 * * * \\
(0.017)\end{array}$ & $\begin{array}{c}0.701 * * * \\
(0.012)\end{array}$ & $\begin{array}{c}0.757 * * * \\
(0.014)\end{array}$ & $\begin{array}{c}0.758 * * * \\
(0.012)\end{array}$ \\
\hline Single male with child & $\begin{array}{c}0.913 \\
(0.046)\end{array}$ & $\begin{array}{l}0.857 * * \\
(0.049)\end{array}$ & $\begin{array}{c}0.861 * * * \\
(0.030)\end{array}$ & $\begin{array}{c}0.823 * * * \\
(0.023)\end{array}$ & $\begin{array}{c}0.846 * * * \\
(0.020)\end{array}$ \\
\hline Married no child & $\begin{array}{c}0.982 \\
(0.015)\end{array}$ & $\begin{array}{c}1.024 \\
(0.021)\end{array}$ & $\begin{array}{c}1.143 * * * \\
(0.025)\end{array}$ & $\begin{array}{c}1.122 * * * \\
(0.027)\end{array}$ & $\begin{array}{l}1.073 * * \\
(0.025)\end{array}$ \\
\hline Single female & $\begin{array}{c}0.883 * * * \\
(0.018)\end{array}$ & $\begin{array}{c}0.978 \\
(0.023)\end{array}$ & $\begin{array}{c}1.111^{* * *} \\
(0.022)\end{array}$ & $\begin{array}{c}1.161^{* * *} \\
(0.026)\end{array}$ & $\begin{array}{c}1.073 * * * \\
(0.019)\end{array}$ \\
\hline Single male & $\begin{array}{c}0.968 \\
(0.020)\end{array}$ & $\begin{array}{l}1.048 * \\
(0.024)\end{array}$ & $\begin{array}{c}1.114 * * * \\
(0.020)\end{array}$ & $\begin{array}{c}1.078 * * * \\
(0.022)\end{array}$ & $\begin{array}{c}1.034 \\
(0.018)\end{array}$ \\
\hline \multicolumn{6}{|l|}{ Education $(<$ HS diploma omitted $)$} \\
\hline Education: HS diploma & $\begin{array}{c}1.057 * * * \\
(0.016)\end{array}$ & $\begin{array}{c}1.102 * * * \\
(0.018)\end{array}$ & $\begin{array}{c}1.307 * * * \\
(0.019)\end{array}$ & $\begin{array}{c}1.262 * * * \\
(0.020)\end{array}$ & $\begin{array}{c}1.267 * * * \\
(0.018)\end{array}$ \\
\hline Education: Some college & $\begin{array}{c}1.177 * * * \\
(0.026)\end{array}$ & $\begin{array}{c}1.375^{* * *} \\
(0.030)\end{array}$ & $\begin{array}{c}1.630 * * * \\
(0.026)\end{array}$ & $\begin{array}{c}1.498 * * * \\
(0.024)\end{array}$ & $\begin{array}{c}1.532 * * * \\
(0.022)\end{array}$ \\
\hline Education: College + & $\begin{array}{c}1.234 * * * \\
(0.040)\end{array}$ & $\begin{array}{c}1.985^{* * *} \\
(0.067)\end{array}$ & $\begin{array}{c}2.502 * * * \\
(0.055)\end{array}$ & $\begin{array}{c}2.034 * * * \\
(0.046)\end{array}$ & $\begin{array}{c}2.129 * * * \\
(0.039)\end{array}$ \\
\hline Total income (In '000s) & $\begin{array}{c}1.031 * * * \\
(0.002)\end{array}$ & $\begin{array}{c}1.023 * * * \\
(0.002)\end{array}$ & $\begin{array}{c}1.017 * * * \\
(0.001)\end{array}$ & $\begin{array}{c}1.011^{* * *} \\
(0.000)\end{array}$ & $\begin{array}{c}1.003 * * * \\
(0.000)\end{array}$ \\
\hline Owner & $\begin{array}{c}1.886^{* * *} \\
(0.030)\end{array}$ & $\begin{array}{c}2.135^{* * * *} \\
(0.038)\end{array}$ & $\begin{array}{c}1.045 * * \\
(0.017)\end{array}$ & $\begin{array}{c}0.856 * * * \\
(0.016)\end{array}$ & $\begin{array}{c}1.166 * * * \\
(0.016)\end{array}$ \\
\hline MSA population (in '000,000s) & $\begin{array}{l}1.001 * * \\
(0.000)\end{array}$ & $\begin{array}{c}0.999 * * * \\
(0.000)\end{array}$ & $\begin{array}{c}0.989 * * * \\
(0.000)\end{array}$ & $\begin{array}{c}0.992 * * * \\
(0.000)\end{array}$ & $\begin{array}{c}0.991 * * * \\
(0.000)\end{array}$ \\
\hline MSA percent black & $\begin{array}{c}0.944 * * * \\
(0.001)\end{array}$ & $\begin{array}{c}0.961^{* * *} \\
(0.001)\end{array}$ & $\begin{array}{c}0.979 * * * \\
(0.001)\end{array}$ & $\begin{array}{c}0.978 * * * \\
(0.001)\end{array}$ & $\begin{array}{c}0.992 * * * \\
(0.001)\end{array}$ \\
\hline MSA Dissimilarity index & $0.002 * * *$ & $0.002 * * *$ & $0.022 * * *$ & $0.132 * * *$ & $0.097 * * *$ \\
\hline
\end{tabular}


Current MSA in South

Constant

Observations

Log-likelihood

Notes: Standard errors in parentheses

$* * * \mathrm{p}<0.001, * * \mathrm{p}<0.01, * \mathrm{p}<0.05$

$\begin{array}{ccccc}(0.000) & (0.000) & (0.002) & (0.009) & (0.006) \\ 0.744 * * * & 0.711 * * * & 0.827 * * * & 1.046 & 0.737 * * * \\ (0.020) & (0.020) & (0.015) & (0.026) & (0.015) \\ 162.635 * * * & 185.541 * * * & 19.001 * * * & 4.942 * * * & 3.930 * * * \\ (11.403) & (14.899) & (1.176) & (0.276) & (0.182)\end{array}$

$170,000 \quad 127,000 \quad 225,000 \quad 222,000 \quad 283,000$

$\begin{array}{lllll}-517,940 & -524,589 & -1,354,669 & -1,796,484 & -2,034,933\end{array}$ 
Table 5. Predicted probabilities of making a pioneering move over time given newcomer status to metropolitan area

\begin{tabular}{|c|c|c|c|c|}
\hline & $\begin{array}{l}\text { Model with no } \\
\text { controls }\end{array}$ & & $\begin{array}{l}\text { Model with } \\
\text { household- } \\
\text { level and } \\
\text { metropolitan- } \\
\text { level controls }\end{array}$ & \\
\hline & Probability & Standard error & Probability & Standard error \\
\hline 1960 & 0.095 & 0.001 & 0.091 & 0.001 \\
\hline 1970 & 0.134 & 0.002 & 0.110 & 0.002 \\
\hline 1980 & 0.344 & 0.003 & 0.306 & 0.003 \\
\hline 1990 & 0.366 & 0.002 & 0.296 & 0.002 \\
\hline 2000 & 0.290 & 0.002 & 0.246 & 0.002 \\
\hline
\end{tabular}


Table 6. Change in segregation between 1970 and 1980 and percent black newcomers

\begin{tabular}{lcc} 
Metropolitan Area & $\begin{array}{c}\text { Change in } \\
\text { Segregation, } \\
1970-80\end{array}$ & $\begin{array}{c}\text { Proportion } \\
\text { black } \\
\text { newcomers, } \\
1975-80\end{array}$ \\
\hline Northeast and Midwest & & \\
Baltimore, MD SMSA & -0.07 & 0.06 \\
Chicago, IL SMSA & -0.04 & 0.04 \\
Cleveland, OH SMSA & -0.03 & 0.05 \\
Detroit, MI SMSA & -0.02 & 0.05 \\
New York, NY-NJ SMSA & 0.00 & 0.07 \\
Philadelphia, PA-NJ SMSA & -0.01 & 0.05 \\
Washington, DC-MD-VA SMSA & -0.11 & 0.10 \\
South & & \\
Atlanta, GA SMSA & -0.04 & 0.13 \\
Austin, TX SMSA & -0.15 & 0.21 \\
Dallas-Fort Worth, TX SMSA & -0.10 & 0.11 \\
Houston, TX SMSA & -0.09 & 0.12 \\
Miami, FL SMSA & -0.07 & 0.16 \\
West & & \\
Anaheim-Santa Ana-Garden Grove, CA & & \\
SMSA & -0.38 & 0.48 \\
Denver-Boulder, CO SMSA & -0.19 & 0.23 \\
Los Angeles-Long Beach, CA SMSA & -0.10 & 0.11 \\
Phoenix, AZ SMSA & -0.23 & 0.23 \\
San Diego, CA SMSA & -0.19 & 0.36 \\
San Jose, CA SMSA & -0.12 & 0.36 \\
Seattle-Everett, WA SMSA & -0.14 & 0.21 \\
\hline
\end{tabular}


Table 7. OLS model predicting changes in the index of dissimilarity, 1970-1980

b

\% black newcomers to SMSA last 5yrs, $1980 \quad-0.420 * * *$

(0.066)

Constant

$-0.029^{*}$

$(0.013)$

Observations

60

R-squared

0.415

Notes: Standard errors in parentheses

$* * * \mathrm{p}<0.001, * * \mathrm{p}<0.01, * \mathrm{p}<0.05$ 